\title{
SIGNIFICANT FEATURES OF GUNUNG SEWU KARST AS GEOPARK SITE
}

\author{
Eko Haryono and Suratman \\ Karst Research Group \\ Faculty of Geography, Gadjah Mada University, Yogyakarta-Indonesia
}

\begin{abstract}
Gunung Sewu is internationally well known for its typical conical karst morphology. It was Lehman who first introduced Gunung Sewu Type to the karst literatures. The term is now used world wide to describe the same morphology as that in Gunung Sewu Karst. The other outstanding morphological feature of Gunung Sewu Karst is the existences of gorge know as ancient Bengawan Solo valley. This gorge records uplift history of Java Island during Quaternary of which the river course turned from southward direction to northward direction. The area has also significant position in human history, since the area is considered as a pre-historic capital city of south-east Asia. Habitation of Gunung Sewu karst has been started since Middle Pleistocene through three phase chronologies. In the early habitation human settlement occupies open space along river courses. When the caves were exposed, human settlement moved to the caves and distributed along dry valleys or near doline ponds. Cave habitations ended when major depression dried out providing extensive agricultural land. The area currently is facing environmental deterioration. To cop with this, local groups including NGO, local people, university, and government have already established Karst Gunung Sewu Management Forum since 2008 which is facilitated by the Ministry of Environmental. Environmental management action plan has been enacted including protection area under Geopark scheme.
\end{abstract}

Keywords: Geopark, Gunung Sewu

\section{Introduction}

The Geoparks initiative was launched by UNESCO in response to perceived need for an international initiative that recognizes sites representing an interest for the earth science. Global Geoparks Network program aims at enhancing the value of such sites while at the same time creating employment and promoting regional economic development. For the purposes of the program the organization developed new internationally recognized label 'UNESCO Geopark'. The idea of UNESCO is to label up to 500 Geoparks worldwide. The UNESCO Geopark Program works in synergy with UNESCO's World Heritage Centre and Man and the Biosphere (MAB) World Network of Biosphere Reserves.

A geopoark is a territory encompassing one or more sites of scientific importance, not only for geological reasons but also by virtue of its archaeological, ecological or cultural value (www.wikipedia.com).

Compared with other Asian countries, Indonesia is considered less developed in protecting geo-diversity. Indonesia with the diverse geological and geomorphologic features should have paid more attention on this program. But no single geological and geomorphologic features in Indonesia are under protection. Protected areas in Indonesia are mostly based on biodiversity protection scheme, especially under national park 
scheme. To keep up with situation, this paper aims at exploring any possibilities that Gunung Sewu karst is protected under geopark scheme. This initiative hopefully will be a starting point on geological and geomorphic conservation in Indonesia and trigger further efforts to protect Indonesian geo-diversity.

\section{The Gunungsewu Karst}

Gunung Sewu karst stretches $85 \mathrm{~km}$ west-east from Parangtritis Beach of Yogyakarta Special Province to Teleng Ria Beach of Pacitan-East Java. The area covers three provinces, namely Yogyakarta, Central Java, and East Java Province. Its northsouth width varies between 10 and $29 \mathrm{kms}$ with approximate area of $1300 \mathrm{~km}^{2}$. The Gunungsewu karst is adjacent to the Indian Ocean on the south central coast of Java (Figure 1). Elevation range is between zero and $512.5 \mathrm{~m}$ above mean sea level, and the highest portions centrally located about $25 \mathrm{~km}$ from the cost line (Haryono and Day, 2004).

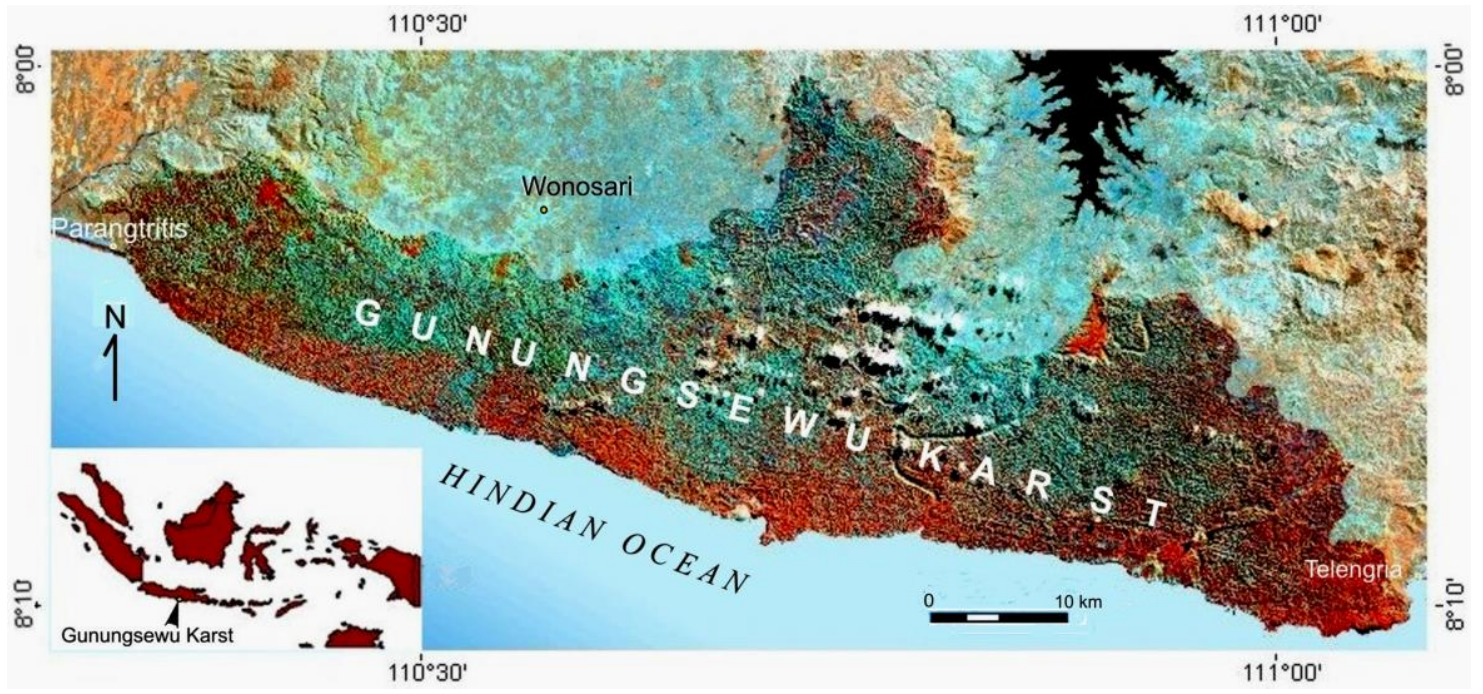

Figure 1. Landsat ETM depicting Gungungsewu Karst and the surrounding areas

The prevailing contemporary climate in the Gunungsewu karst is strongly influenced by the Northwest and Southeast monsoons, which produce a distinct wet season from October to April and a dry season, which may be extremely arid, between May and September. The annual rainfall, recorded from 14 local rain gauge stations between 1960 and 1997 varies between $1500 \mathrm{~mm}$ and $2986 \mathrm{~mm}$ annually. Mean annual temperature is about $27^{\circ} \mathrm{C}$ (Haryono and Day, 2004).

\section{The Geological Setting}

The Gunungsewu karst is made up of Neogen (Middle Miocene and Upper Pliocene) limestone the so-called Wonosari-Punung Formation (Tmwp). The limestone 
is composed of massive coral limestone in the south and bedded chalky limestone in the north (Balazs 1968; van Bemmelen 1970; Waltham et al. 1983; Surono et al. 1992; Rahadjo et al., 1995). Total thickness of the limestone exceeds $650 \mathrm{~m}$. The coral reef limestone is lithologically highly variable, but dominated by rudstones, packstones, and framestones. Biohermal structures are identifiable, and lenses of volcanic ash are interspersed among the carbonates (Waltham et al. 1983). The bedded, chalky limestones become more prominent towards the north and northeast, and dominate the Wonosari Plateau. The underlying rocks of Wonosari-Punung Formations mostly are volcanic clastic sedimentary rocks of Miocene Epoch (Wuni F., Sambipitu F., Semilir F., Nglanggran F., and Nampol F.). These formations are interchangeable found in some localities being the basements of Gunung Sewu Karst.

The Wonosari-Punung Formation was uplifted during the late Pliocene and/or early Pleistocene and dipping gently southward at about a $2 \%$ gradient, being marked by a high cliff (25-100 m) along the south cost (Balazs 1968; van Bemmelen 1970; Surono et al. 1992; Sutoyo 1994). North-south compression associated with tectonic plate convergence produced deformation including intensive northwest-southeast and northeast-southwest jointing and faulting (Balazs 1968; van Bemmelen 1970; Surono et al. 1992; Sutoyo 1994, Haryono, et al., 2005). The structure is most complex along the northern boundary.

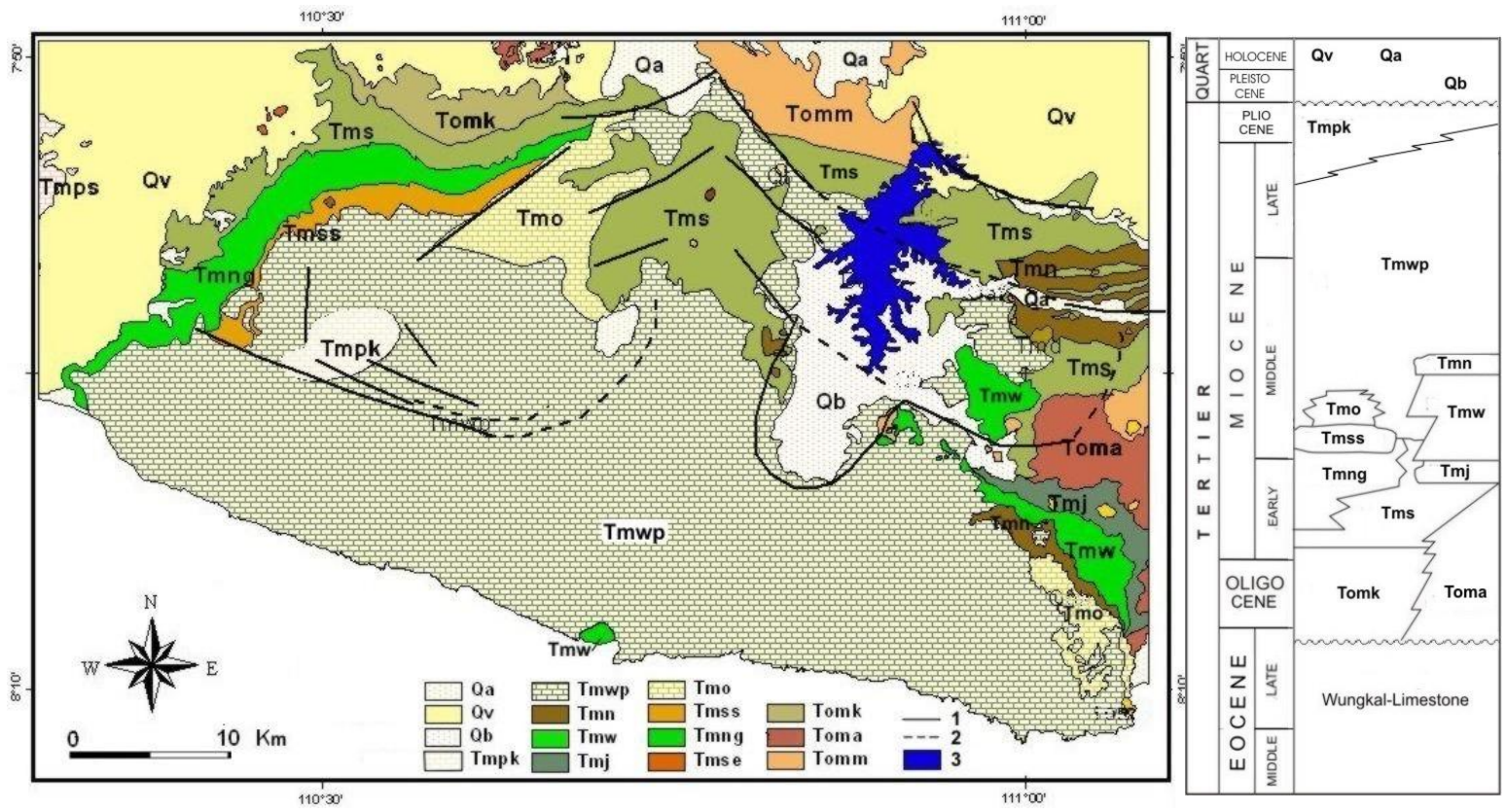

Figure 2. Geological map of Gunungsewu Karst and the surrounding areas Qa: Alluvium of Fluvial Deposits; Qv: Alluvium of fluvio-volcanic deposits; Qb: Alluvium of Baturetno Formation; Tmpk: Kepek Formation; Tmwp: Wonosari-Punung Formation; Tmn: Nampol Formation; Tmw: Wuni Formation; Tmj: Jaten Formation, Tmo: Oyo Formation; Tmss:Sambipitu Formation; Tmng: Nglangran Formation; Tms: Semilir Formation; Tomk: Kebobutak Formation; Toma: Arjosari Formation; Tomm: Mandalika Formation (Compiled from Bemelen, 1970; Surono et al., 1992; and Rahardjo et al., 1995) 


\section{The significant features of Gunung Sewu Karst as Geopark site}

\section{a. Geological Historical significant}

Gunungsewu Karst physiographically is part of the southern mountain of Java Island (van Bemmelen, 1970), being discontinues hilly range forming plateau morphology (Pannekoek, 1949). The southern mountain was resulted from block uplifted peneplain starting from Late Pliocene. In the northern border, the southern mountain is separated by fault scarp from depression zone of Java. The Gunungsewu Karst itself lies in the eastern section of this hilly range separated from the middle and western part by Graben Bantul. In this section the southern mountain was subjected to faulting and down warping forming Wonosari Depressions and Baturetno Depression within which karstification is limited. The karst surface within the depressions is mantled by deeply weathered clays, up to $10 \mathrm{~m}$ in thickness, which are remnants of volcanic ash, intermixed with weathering residue from the limestones (Waltham et al. 1983, Samudra, 1983). These two depressions separated the Gunungsewu Karst in southern part with the volcanic clastic sedimentary rocks in northern part of the southern mountain. These two depressions were resulted from sinus flexure of peneplain, accompanied by small faults, dipping toward the basin.

Uplifting of the area also resulted in several marine terraces and abandoned valley of Archaic Solo River. Reconstructions of the marine terraces were performed by Urushibara (1997), Brahmantyo (198). Three major marine terraces were readily recognized either from satellite imagery or contour map. Identification by the author from DEM derived from 1:25,000 scale topographical map shows that the lowest marine terrace is estimated at the altitude of $112,5 \mathrm{~m}( \pm 12.5 \mathrm{~m})$ above present average sea level (asl), The middle terraces are about $137.5 \mathrm{~m}( \pm 12.5 \mathrm{~m})$ asl, whereas the highest ones are about $200( \pm 12.5 \mathrm{~m})$ asl. Minor terraces were also identified by Urushibara (1997) at the approximate altitude of $50 \mathrm{~m}$ asl, showing well-shaped cones and dolines at about $20 \mathrm{~m}$ asl with extremely small cones and only shallow surface depressions. The marine terraces are also confirmed by the occurrence of cave levels and river terraces at the Sadeng dry valley (Urushibara, 1997) and Baksoka River (Bastra, 1976). Three river terraces, dry cave system, and notches around the mouth of the dry valley are well developed.

Another distinctive morphological feature in the Gunungsewu karst is abandoned/dry valley of former Bengawan Solo River. The Bengawan Solo River that is currently flowing northward to the Java Sea used to flowing southward to the Hindian Ocean sculpturing this abandoned valley (Pannekoek, 1949: Bemmelen, 1970; Urushibara, 1997; Marwanto et.al., 1999). The dried up of the valley was associated with the uplift of southern part of Southern Mountain. This uplift wrapped down the northern part forming depression (previously mentioned Baturetno Basin) and cutting 
down the former Bengawan Solo River course. Morphological evidence of this wrapping down can be traced through the hanging valley in the southern vicinity of Baturetno Basin Marwanto et al. (1999). Urushibara (1997) suggested that the formation of dry valleys in Gunung Sewu was also conditioned by lowering of sea-level, and establishment of a cool and extremely dry climate. The depth of the dry valley varies between 150 and 250 meter and 450/ wide.

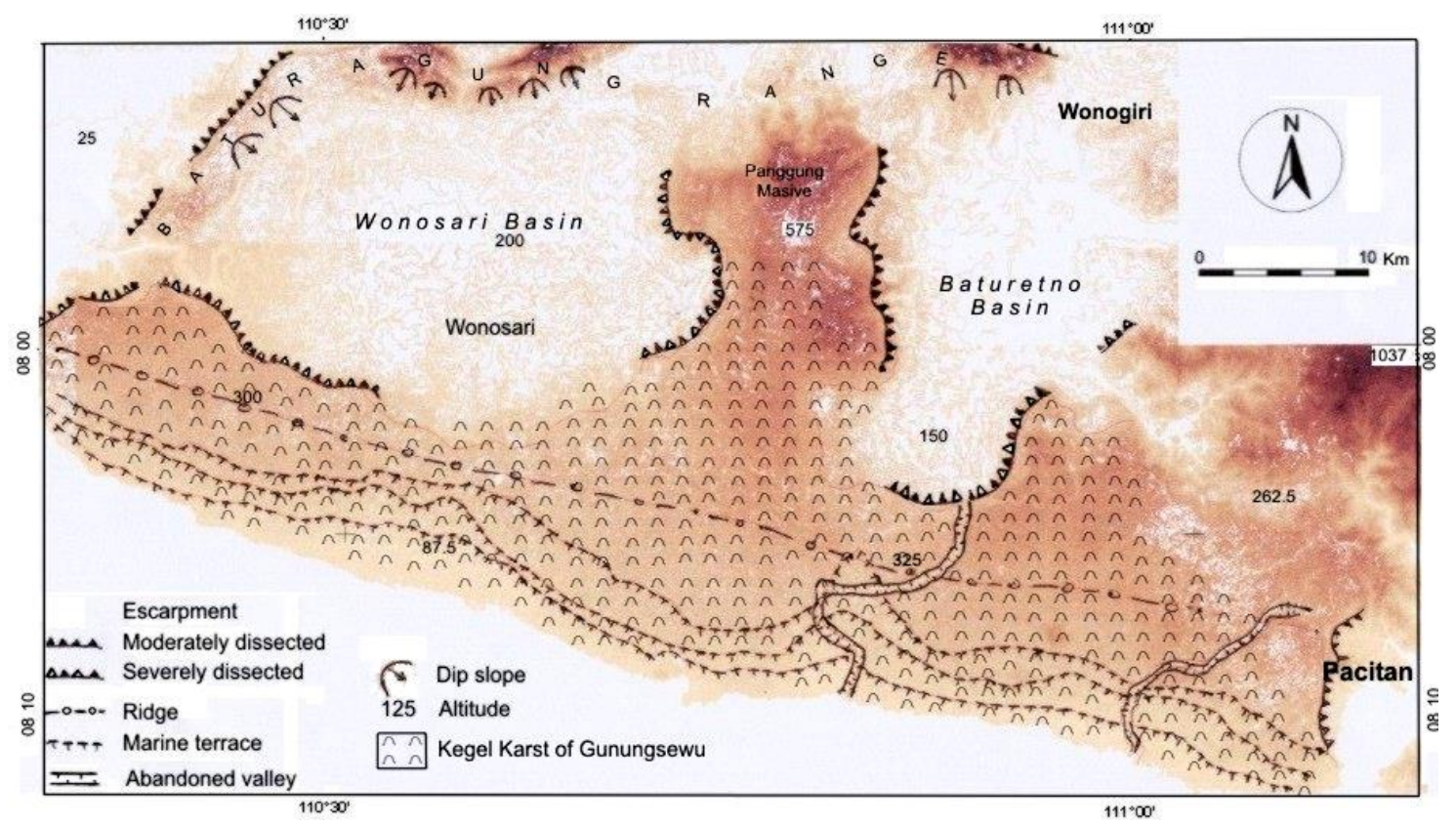

Figure 3. Morphological sketch map of Gunungsewu Karst and the surrounding areas

\section{b. Morphological Significants}

Gunungsewu karst has been subjected to severe karstification forming tropical karst morphology, the so-called cone or kegel karst. This peculiar type of landform was first reported by Lehmann (1936) and has named as Gunung Sewu Type in morphologic glossaries. Flathe and Pfeiffer (1965), however, preferred using sinoid rather than conical karst to describe the Gunungsewu Karst. Resent work by Haryono and Day (2004) unveiled three variation of the Gunungsewu Kegelkarst to which they described as labyrinth-cone karst, residual-cone karst, and polygonal-cone karst.

Labyrinth-cone karst of Gunungsewu Karst is characterized by development of distinctly linear valleys rather than enclosed depressions, and is dominantly controlled by faults or major joints. In the area, the valley linearity is combined with intervening conical hills. The valleys are dry under normal circumstances. Between the valleys are elongated, interfluvial residual hills, $80-100 \mathrm{~m}$ in height, which form long, serrated, ridge-like chains of conical or flat-topped hills without intervening closed depressions. Polygonal-karst is characterized by densely packed or coalesced depressions (cockpits) 
and dismembered meandering valley networks. Although owing much to dissolution, the polygonal karst of Gunungsewu Karst appears to be strongly influenced by fluvial processes and by the general southerly slope of the plateau. The residual-cone karst is characterized by conical isolated hills scattered on corrosion plain. The latter karst morphology develops in chalky limestone in which the rocks are less hard and high soluble.

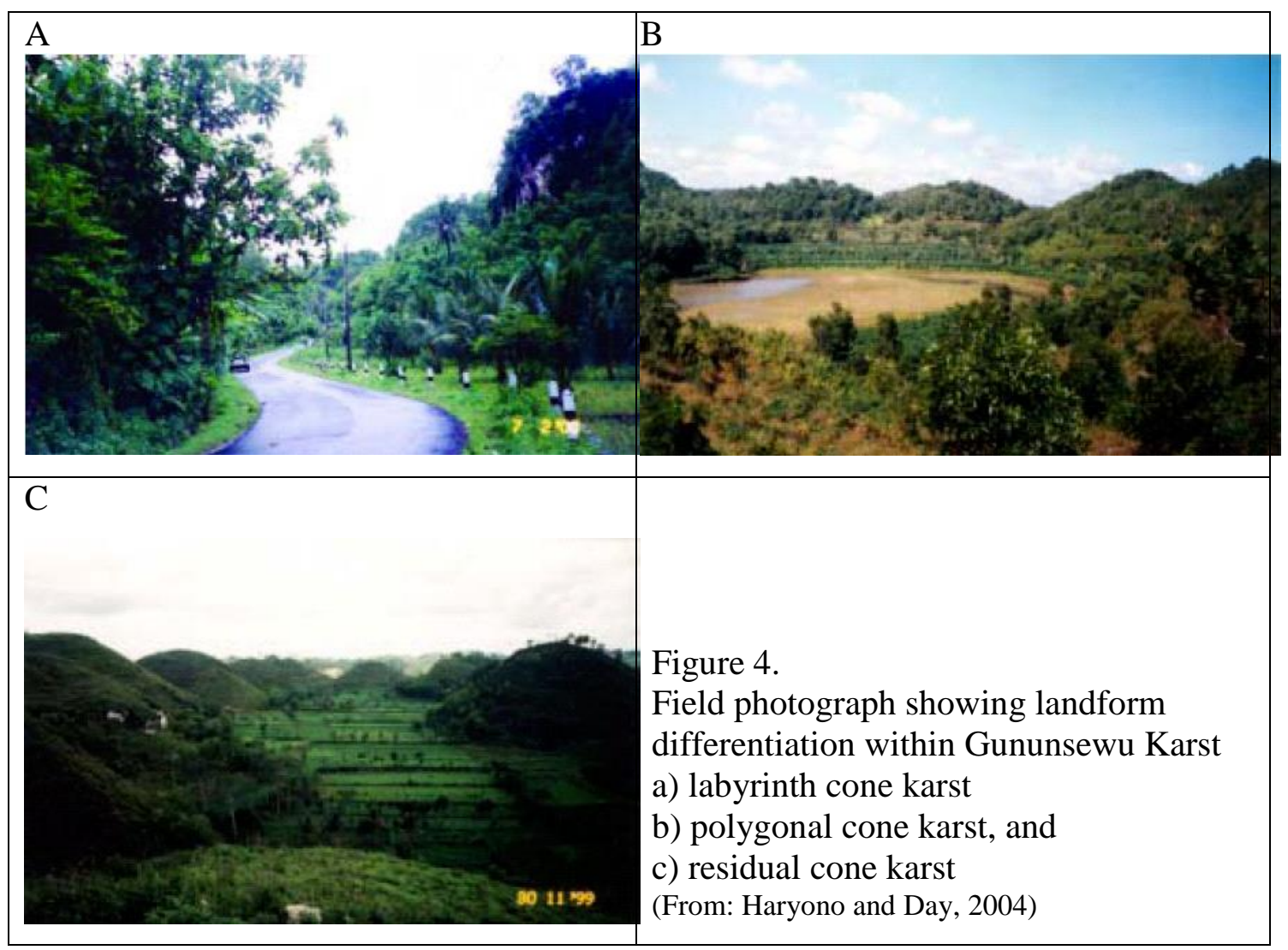

\section{c. Archaelogical Significants}

Gunungsewu Karst has been experiencing long history of settlements. Many archaeologists believe that the oldest human kind of Java was from this area. Widespread caves must have provided good shelters that were readily inhabited. Archaeological exploration and excavation have been conducted since early 1990s. The first archaeological works in Gunungsewu Karst was conducted by von Koenigwald and Tweedie in 1935. They were inspired by the finding of Hominid fossils along Bengawan Solo River of which its upstream is from hilly terrain near karst areas of Punung. The remains of cultural evolution from Palaeolithic toward hunting and agriculture can be reconstructed from here (Yuwono, 2004). The artifacts that have been found from 
Gunungse karst have given significant contribution to the archaeological Pre-Historic theory of Indonesian and south-east Asia.

Koningwald and Tweedie (1935) found very dense scatters of lithic artifacts in Gunungsewu Karst. The implements are generally made of pink (reddish) dark brown blackish silicified tuff, opaque white silcified limestone, and some fossil wood. The artifacts were collected from riverbed of Baksoko River, mixed with pebbles. There are also massive tools still attached to conglomerate boulders on the slopes of the riverbank about 3-4 meters from the bottom of the river. (Simanjutak, 2002). In additions to tools, Koningwald and Twedee found the existence of Ursus sp, Tapirus sp, Stegodon, Simia, Elephas namadicus, Echinosore, Symphalangus, and Hylobates.

Comprehensive culture evolution of Gunungsewu Karst was presented by Simanjutak (2002) as it is summarized in the following paragraphs. The artifacts found in the Baksoko River were then named as Pacitanian Culture derived from Pacitan, the nearest town of the area. Pacitanian culture was said to be Middle Pleistocene. This age is confirmed by recent finding of Semah and Semah in 1999 that have succeeded in obtaining habitation chronology covering from 180,000 to 4,500 in Terus Cave. This finding suggests that Pacitanian Culture is older than 180.000. Choppers represent the highest percentage of the massive tools, in addition to flake tools. The flat-iron and horse hoof type are characteristic of the Pacitan Culture. Von Koningwald concluded that the tool found from the area had characteristic attributes of Chellean hand-axes. The creator of Pacitanian Culture however, however, is still unclear. No tools found in the area were associated with hominid fossils.

During the late Pleistocene (40,000 until 12,000), there was change of cultural phenomenon. During this period habitations moved to caves or rock shelters from those previously along the river sides. This change had a great impact on cultural development. Life in temporary camps which had previously tended to be nomadic changed to more settled life in cave. This condition facilitated opportunities for innovations. Some typical characteristics of the late Pleistocene are 1) exploitation of caves and rock shelters for habitation and other activities, 2) exploitation of various kinds of rocks for tools, 3) subsistence by hunting, and 4) hominid culture bearers belonging to the species of Homo sapiens (Simanjutak, 2002).

Numerous lithic artifacts of waste flakes and flacking tools in the cave indicate that caves also serve as workshop for lithic toll making. However lithic technology was not developed during this period, inferring from rarity of remains compared to waste flacks. The quantity of artifacts gradually decreased in deeper levels. The lithic artifacts tend to be denser in the upper layers indicates that the lithic industry was developed rapidly near the Pleistocene-Holocene transition. Beside lithic tools, the cave dwellers have started to make implements from animal bones, although not as intensive as in the 
Holocene. The main source of subsistence during the late Pleistocene was hunting of game in the surrounding areas of the caves.

Lithic industry reached their peak in the first half of Holocene. The product of lithic industry consisted Paleolithic, Preneolithic, and Neolithic. Paleolithic tools are core tools from limestone as chopping tools and choppers. Preneolithic traits were represented by flakes and blades, whereas Neolithic traits were represented by quadrangular adzes of limestone, mollusk shell, and bone fossils. Flake tools are the most common industry of Gunung Sewu Karst. Beside lithic industry, a bone industry was very well developed in Gunungv Sewu karst, especially during Early Holocene. Bone tools in the area are classified as spatulas, points, needles, and tools made of antler.

The Neolithic of Gunung Sewu karst displayed unique characteristics with regards to its geographical orientation, technological aspect, and chronology. In the beginning, Neolithic technology was still centered in caves and shelters, representing continuation of the Preneolithic culture. Subsequently Neolithic sites shifted to open sites on plains and hill slopes. The shift from cave to open sites apparently was related to technological development. The plains and hill slope where chert is easy to get for adze manufacturing, were selected as locations for settlements and workshops, rather than caves Advancements in technology made it possible to exploit trees to build simple houses around the workshop. Neolithic culture is presumed started from 4,000 BP up to 2,000 BP.

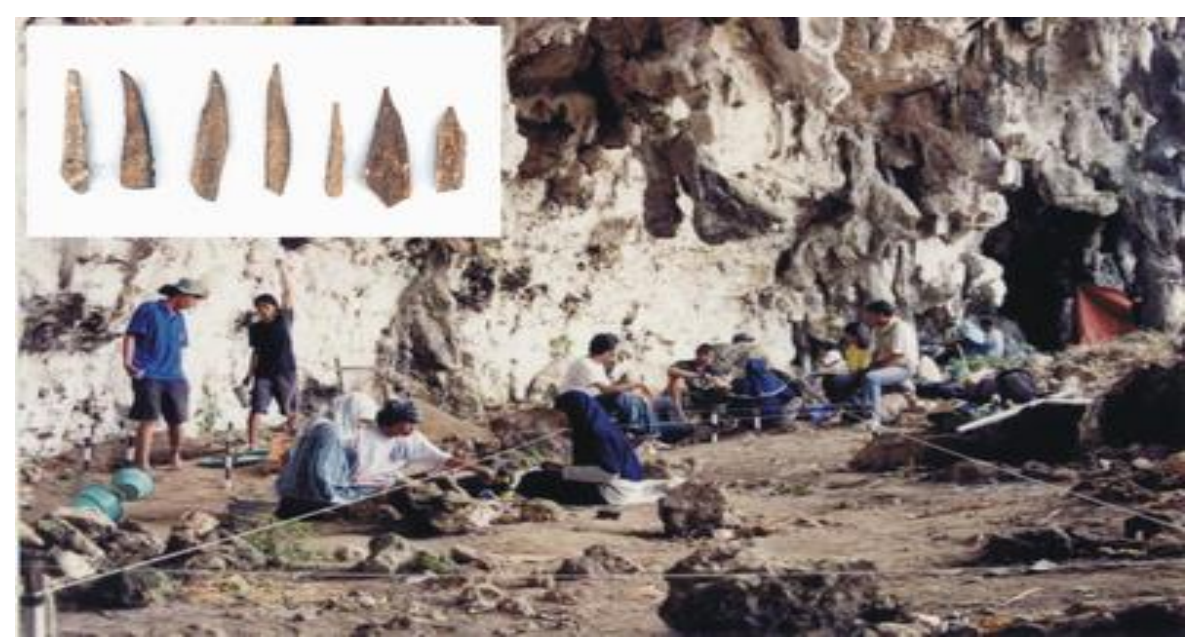

Figure 5. Typical of sheltered cave interior in Gunungsewu Karst. Inset is points from early Holocene industry From: Yuwono, 2004 with the courtesy of PTKA UGM

The prehistoric time of Gunungsewu Karst was ended in Paleometalic Era. in this era pottery making become more advanced, characterized by the use of paddle and anvil, combine with the use of potter's wheel and polishing technology. The time span covered by Paleomethalic culture was shorter than that of Neolithic. This culture still existed 700 
years ago. This culture did not last long as evidenced by the thinness of the cultural layer in the excavation site.

Gunungsewu prehistoric time culture was prolonged. When the lowland areas and volcanic areas experienced Hindus culture, Gunungsewu Karst still carried on prehistoric culture until better access was opened from the lowland surrounding areas. Hindus culture in Java island has started since the $4^{\text {th }}$ century compare to that in Gunungsewu Karst where no inscriptions were found (Yuwono, 2005, oral communication). As stated before, during $4^{\text {th }}$ century, Gunungsewu Karst was still undergoing Paleometalic Era.

\section{Bibliography}

Balazs, D, 1968, Karst Regions in Indonesia: Karszt-Es Barlangkutatas, Volume V. Budapest.

Bastra GJ, 1976, Contribution to the study of the Paleolithic Pacitan Culture, Java Indonesia, Part I Proefschrift, Leiden: EJ Brill.

Brahmantyo B, Puradimaja DJ, Bandono and Sadisun IA, 1998: Interpretasi kelurusan dari citra SPOT dan hubungannya dengan pola pengaliran bawah tanah pada Perbukitan Karst Gunungsewu, Jawa Tengah bagian selatan, Buletin Geologi, 28 (1), 37-49.

Flathe H and Pfeiffer D, 1965, Grundzuge der morphologie, Geology und Hydrogeologie im Karstgebiet Gunung Sewu (Java, Indonesien): Geologisches Jahrbuch, 83, 533-562.

Haryono E and Day M, 2004, Landform differentiation within the Gunung Kidul Kegelkarst, JavaIndonesia, Journal of Cave and Karst Studies, 66 (2), 56-63.

Haryono, Hadi MP, Suprodjo SW, Sunarto, 2000, Kajian Mintakat Epikarst di Kabupaten Gunungkidul untuk Penyediaan Air Bersih, not Published, Laporan PHB VIII, Universitas Gadjah Mada, Yogyakarta.

Haryono E, Nurcahyo AD, Gunawan T, Purwanto HP, 2005, Underground river networks modeling from lineaments and fracture traces by means of remote sensing and geographic information system, in Stevanovic Z and Milanovic P, Proceeding of International Conforence 'Water Resources and Environmental Problems in Karst', Belgrade-Kotor, 569-574.

Lehmann, H, 1936, Morphologische Studien auf Java, Geographische Abhandlungen, 3 (9). 1-114.

Marwanto H, Subandrio A, Riyanto ABN, and Suharsono, 1999, Study of the Trace of Ancient Solo River in the Southern Wonogiri, Central Java, UPN 'Veteran', Yogyakarta.

Pannekoek AJ,1949, Outline of The Geomorphology of Java, Leiden.

Rahardjo W, Sukandarrumidi, Rosidi HMD, 1995, Geological Map of The Yogyakarta Sheet, Java, Geological Research an Development Centre, Bandung

Samudra, 1983, Geologi dan studi bahan galian di Kecamatan Karangmojo dan Semanu, Kabupaten Gunungkidul, Undergraduate Thesis, not Published, UPN 'Veteran', Yogyakarta.

Simanjutak T., 2002, Gunungsewu in Prehistoric Times, Gadjah Mada University Press, Yogyakarta.

Surono, BT, Sudarno I and Wiryosujono S, 1992, Geology of the Surakarta-Giritontro Quadrangles, Java, scale 1:100,000, Geological Research and Development Center, Bandung.

Sutoyo, 1984: Sikuen stratigrafi karbonat Gunungsewu, in Busono, I., Syarifudin, N., Alam H. (eds), Proceedings pertemuan ilmiah tahunan IAGI ke 23, Jakarta.

Urushibara-Yoshino K and Yoshino M, 1997, Palaeoenvironmental change in Java Island and its surrounding areas: Journal of Quaternary Science, 12(5), 435-442.

van Bemmelen RW, 1970, The Geology of Indonesia, Volume 1A, General Geology: The Hague, Martinus Nijhoff.

Waltham AC, Smart PL, Friederich, H, Eavis, A.J \& Atkinson TC, 1983, The caves of Gunung Sewu, Java:, Cave Science, 10(2), 55-96.

Yuwono SE, 2004, Mozaik purba gunung sewu: hipotesis hasil eksplorasi gua-gua arkeologis di Kecamatan Tanjungsari - Gunungkidul, Arthropoda gua karst gunung sewu : sebuah tinjauan, Gunung Sewu: Indonesian Cave and Karst Journal, I(1), 40-51. 